\title{
RIGIDIFIED MALONONITRILE- AND KETONE-MEROCYANINES IN RIGID ENVIRONMENTS•
}

\author{
Tomče Runčevski ${ }^{1 *}$, Katharina C. Kre $\beta^{2}$, Nanna Wahlberg ${ }^{3}$, Robert E. Dinnebier ${ }^{1}$, \\ Sabine Laschat ${ }^{2}$ \\ ${ }^{I}$ Max Planck Institute for Solid State Research, Heisenbergstrasse 1, D-70569 Stuttgart, Germany \\ ${ }^{2}$ Universität Stuttgart, Pfaffenwaldring 55, D-70569 Stuttgart, Germany \\ ${ }^{3}$ Department of Chemistry, Aarhus University, Langelandsgade 140, DK-8000 Aarhus C, Denmark \\ *t.runcevski@fkf.mpg.de
}

Two merocyanine dyes containing a malononitrile or a ketone functional group as electronacceptors, and a piperidine group as electron-donor were synthetized and crystallized as pigments. The electron-donor and -acceptor moieties are linked via an octahydroanthracene skeleton, forming an electronic push-pull molecular system. The crystal structure of the malononitrile compound was solved $a b$ initio from X-ray powder diffraction data, complementing the reported structure of the ketone pigment. Both compounds show similar molecular conformations in the solid state, yet with completely different crystal packing schemes. The crystal structures were analyzed by inspecting the Hirshfeld surfaces. IR spectroscopy was applied to complement the crystallographic study. The absorption characteristics of both pigments emerge from the push-pull chemical structure, which was visualized by plotting the electrostatic potentials, calculated using molecular geometries as observed in the solid state. The solid-state UV-vis spectra showed peak broadening and bathochromic spectral shift as compared to the spectra recorded in solution, depending on the polarity of the solvent molecules: The largest shifts of the spectra of solid-state pigments were observed with respect to the spectra recorded in toluene solution, whether the smallest to those in ethanol.

Keywords: pigments; dyes; crystal structure; powder diffraction; IR spectroscopy; UV-vis spectroscopy

\section{СТВРДНАТИ МАЛОНИТРИЛ- И КЕТОН-МЕРОЦИЈАНИНИ ВО РИГИДНИ СРЕДИНИ}

Две мероцијанатни бои, составени од малонитрилна и кетофункционална група како електронски акцептори и пипиридинска група како електронски донор, беа синтетизирани и кристализирани како пигменти. Електронските донорни и акцепторни групи се поврзани со октахидроантраценски скелет и формираат т.н. пуш-пул молекуларен систем. Кристалната структура на малонитрилното соединение беше решена за прв пат, аб иницио, со рендгенска дифракција од прашок. Двете соединенија имаат слични молекулски конформации во цврста состојба, но со целосно различно пакување во кристалната решетка. Кристалните структури беа проучени со анализирање на соодветните Хиршфелдови површини. Кристалографската студија беше дополнета со резултати добиени од инфрацрвена спектроскопија. Апсорпционите карактеристики на двата пигмента потекнуваат од хемиската пуш-пул структура, којашто беше набљудувана преку обликот на електростатските потенцијали, пресметани користејќи ја молекуларната геометрија присутна во цврста состојба. Ултравиолетовите спектри во цврста состојба покажуваат проширување на апсорпционите ленти и батохромно спектрално поместување, споредено со спектрите снимени во раствор. Спектралното поместување зависи од поларноста на молекулите на растворувачот: најголеми поместувања на спектрите на цврстите

\footnotetext{
- Dedicated to Academician Gligor Jovanovski on the occasion of his $70^{\text {th }}$ birthday.
} 
пигменти се забележани во однос на спектрите снимени во толуен, додека пак најмали поместувања се забележани во однос на спектрите снимени во етанол.

Клучни зборови: пигменти; бои; кристална структура; дифракција од прашок; инфрацрвена спектроскопија; ултравиолетова спектроскопија

\section{INTRODUCTION}

Organic functional dyes recently attracted much attention as novel functional materials with a wide range of applications, for example in molecular memories and switches, food storage, photosensitive pharmaceutics, photodynamic tumour pharmaceutics, dye-sensitized optical elements [1-9]. Current research challenges are prediction, optimization and ultimately control of their physical properties, such as optical absorption, emission, long-term stability, processability and reproducibility. Studies on their solid-state properties are particularly important, as these materials are used in many devices, for example in dye-sensitized solar cells or as pigments.

Merocyanines (MCs) are interesting organic dyes due to the complex solvatochromism of their absorption and fluorescence and their non-linear optical properties [7-9]. MCs are chemically designed by linking an electron-donor with electronwithdrawing functional group by a conjugated chain (Fig. 1a). Conjugated chains are prone to conformational isomerization (especially in solution and gas phase) due to free rotation around the single bonds. It was shown that conformational changes and isomerization of MCs directly correlate with decreased long-term stability, which is a strong limitation to practical applications. One way to overcome these problems is to increase the rigidity of the flexible chromophoric unit, thus decrease its conformational flexibility [8]. This interesting concept was recently applied in the synthesis of chemically rigidified derivatives containing ketones or malononitriles (Fig. 1b). Moreover, the variation of the length of the conjugated core and the type of acceptor group was correlated to the optical and other physical properties in solution [9]. We decided to bring this interesting concept a step further and explore the influence not only of a chemically rigidified chromophore unit, but of a completely rigidified chromophore environment. Namely, in the crystalline state molecules are densely and orderly packed and their ability to move and isomerize is strictly limited within the close packing. MCs are well known for their solvatochromism, thus it is interesting to observe the changes of the chromophore's absorption properties when surrounded by molecules of its own kind. This can be achieved either in highly concentrated solutions or in the solid state.

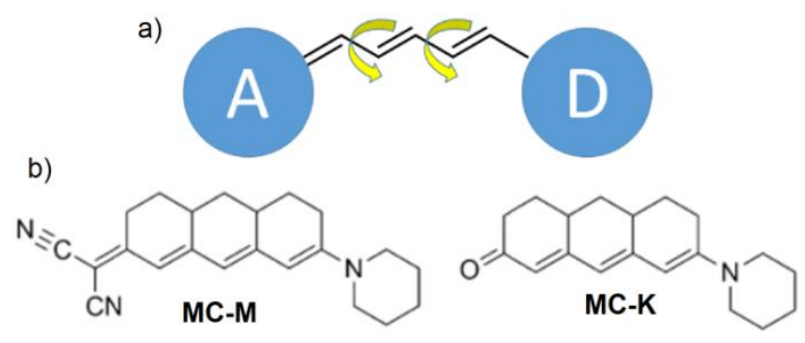

Fig. 1. a) Electron-acceptor (A) and electron-donor (D) functional groups linked by a conjugated chain (regions of rotational flexibility are indicated with yellow arrows). b) Chemical formulae of the studied compounds, MC-M and MC-K.

We selected to study two of the rigidified MCs containing different electron-acceptors, a malononitrile and a ketone functional group, abbreviated as MC-M and MC-K, respectively. The crystal structure of $\mathbf{M C}-\mathbf{K}$ was presented and briefly commented in a previous publication [9], whether the structure of MC-M (which crystallizes only as a polycrystalline bulk) was solved ab initio using X-ray powder diffraction (XRPD). Note that beside the advances in instrumentation and software, crystal structure solution of organic molecules by XRPD still appears to be a niche method. The crystal packing features were analyzed by inspecting the Hirshfeld surfaces [10]. The electrostatic potentials (ESPs) of the molecules in the solid state were calculated using the molecular geometries as observed in the crystal structure determination [11]. Infrared (IR) spectroscopy was used to complement the structural study, detecting the characteristic vibrational signatures of the functional groups. The optical properties were studied by UV-vis spectroscopy and a comparison of the UV-vis spectra, recorded in different solutions and in the solid state, was made. In this article we report on those findings.

\section{EXPERIMENTAL}

\subsection{Materials synthesis and crystallization}

The synthesis of the MCs is detailed in a previous publication [9]. In order to screen for po- 
lymorphic modifications, samples of $\mathbf{M C}-\mathbf{M}$ and MC-K were recrystallized from ether, dichloromethane and benzene. The choice of solvents was limited by the solubility of the compounds. Only one crystal modification of each compound was obtained. Recrystallizations of MC-K led to single crystals. On the contrary, MC-M always solidified in form of a polycrystalline powder.

\subsection{X-ray powder diffraction and structure solution of $\boldsymbol{M C}-\boldsymbol{M}$}

For the solution and refinement of the crystal structure of MC-M, a XRPD pattern (Figure 2) was collected on a Stoe Stadi-P high-resolution laboratory diffractometer with $\mathrm{CuK \alpha _{1 }}$ radiation from primary $\mathrm{Ge}(111)$-Johannson-type monochromator and Dectris-MYTHEN 1K strip position sensitive detector (PSD) with an opening angle of $12^{\circ}$ in $2 \theta$, in Debye-Scherrer geometry (Table 1). Prior to measurement, the sample was manually powdered in a mortar and sealed in a borosilicate glass capillary of $0.5 \mathrm{~mm}$ diameter (Hilgenberg glass No. 50). The sample was spun during data collection for better particle statistics.

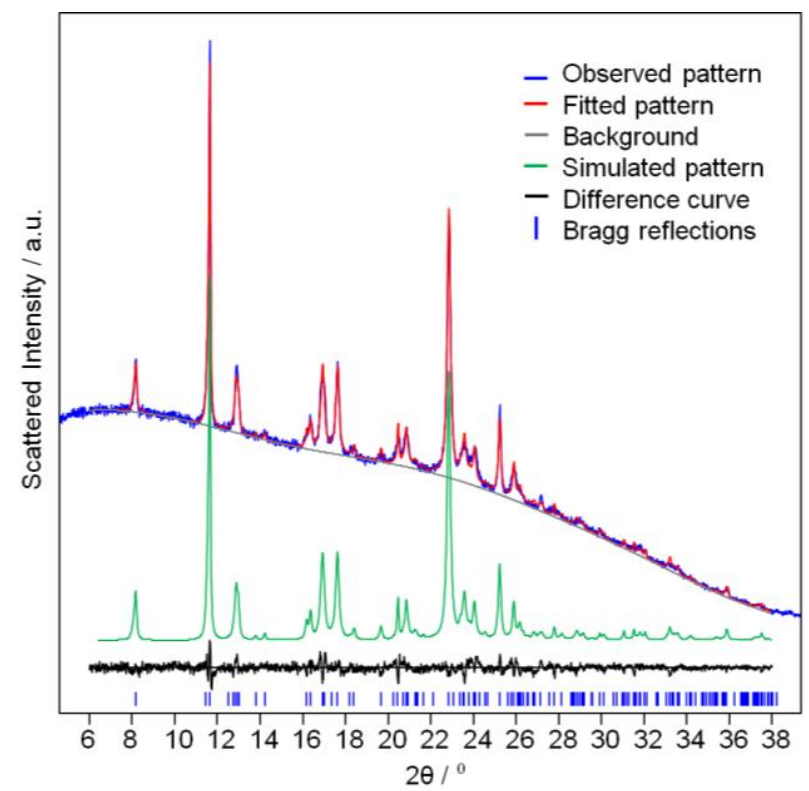

Fig. 2. Rietveld plot of the scattered X-ray intensity of MC-M presented as a function of $2 \theta$ angle, collected at room temperature with $\mathrm{CuK \alpha _{1 }} \mathrm{X}$-ray radiation source

The powder diffraction data analysis (pattern indexing, profile fitting, crystal structure solution and refinement) was performed with the program suite TOPAS 4.2. [12]. The experimental diffraction powder pattern was indexed with the singular value decomposition method [13]. Precise lattice parameters were determined by Pawley fit [14] using the fundamental parameter approach for peak fitting. During the full profile decomposition, lattice parameters, strain and crystallites size contributions were refined. In addition, Chebyshev polynomials were used to model the background. The crystal structure was solved by the global optimization method of simulated annealing (SA) in real space [15]. A rigid body of the molecule, defined in z-matrix notation, was freely rotated and translated within the unit cell with all of its torsion angles set flexible. A variable temperature factor for each atom type was included in the SA process. Once a global minimum was found, the crystal structure was subjected to Rietveld refinement (the bonds within the rigid body were also refined) [16]. The anisotropy of width and asymmetry of the Bragg reflections, caused by structural defects and stacking faults, was successfully modelled by applying symmetry adapted spherical harmonics of sixth's order to Gaussian, Lorentzian and exponential distributions which where convoluted with geometrical and instrumental contributions to the final peak profile. The final Rietveld plot of MC$\mathbf{M}$ is given in Figure 2 and selected crystallographic details in Table 1. Further information on the crystal structure can be found in the CIF file deposited under the reference code CCDC 1061469. Details on the crystal structure of MC-K can be found in the literature [9] and by citing the reference code CCDC 955695.

Table 1

Selected experimental and structural details for the data collection and crystal structure of $\mathbf{M C}-\mathbf{M}$

\begin{tabular}{|c|c|}
\hline Molecular formula & $\mathrm{C}_{22} \mathrm{~N}_{3} \mathrm{H}_{25}$ \\
\hline Wavelength $(\AA ̊)$ & 1.540596 \\
\hline Geometry & Debye-Scherrer \\
\hline Starting and final angle $\left({ }^{\circ} 2 \theta\right)^{[\mathrm{a}]}$ & $6-38$ \\
\hline Data collection time $(\mathrm{h})$ & 24 \\
\hline Temperature $\left({ }^{\circ} \mathrm{C}\right)$ & 25 \\
\hline Space group & $P 2_{1} / n$ \\
\hline$Z$ & 4 \\
\hline$a(\AA \dot{)})$ & $15.231(4)$ \\
\hline$b(\AA)$ & $15.415(4)$ \\
\hline$c(\AA ́)$ & $7.7912(9)$ \\
\hline$\beta\left({ }^{0}\right)$ & $92.575(7)$ \\
\hline$V\left(\AA^{3}\right)$ & $1827.39(6)$ \\
\hline$R-\operatorname{Bragg}(\%)$ & 0.533 \\
\hline$R-\mathrm{p}(\%)$ & 1.054 \\
\hline$R$-wp (\%) & 1.426 \\
\hline
\end{tabular}

[a] Diffraction data were collected up to $70^{\circ} 2 \theta$, however no reflections were observed after $38^{\circ} 2 \theta$. 


\subsection{Crystal packing analyses}

The crystal packing features of MC-M and MC-K were analyzed by the program CrystalExplorer [17]. The Hirshfeld surfaces of the molecules were calculated and presented at 0.008 au [10]. For the analyses of the ESP, the surfaces were plotted at isovalue of $0.008 \mathrm{e} \mathrm{au}^{-3}$. For the calculations of the wavefunctions for both molecules, a STO-3G basis set was used at HartreeFock level of theory, as implemented in the programs CrystalExplorer and Tonto [11]. The molecular geometries for the calculations were taken from the crystal structures.

\subsection{Optical spectroscopy}

Samples were spin-coated on a Herasil glass plate $\left(1 \mathrm{~cm}^{2}\right)$ out of a dichloromethane solution. The spectra were collected using Cary 5000 UV-Vis-NIR instrument and they were analyzed with the Cary WinUV software.

\subsection{Vibrational spectroscopy}

For measuring the Fourier-transform IR spectra of the samples in the solid state, a Bruker Alpha FT-IR spectrophotometer was used, operating in transmission geometry. The spectroscopic data were analyzed by the OPUS 7.2 software.

\section{RESULTS AND DISCUSSION}

\subsection{Crystal structures of $\mathbf{M C}-\mathbf{M}$ and $\boldsymbol{M C}-\boldsymbol{K}$}

MC-K crystalizes in form of single crystals suitable for structure determination by single crystal X-ray diffraction [9]. MC-M, on the contrary, crystallizes as microcrystalline bulk (regardless of our various efforts to obtain single crystals by recrystallization from different solvents). Accordingly, its crystal structure was solved ab initio from XRPD data. Note that although the deviation of precise intramolecular parameters (for example bond lengths and angles or especially thermal displacement factors) by XRPD is hampered by intrinsic problems and limitations of the method, the intermolecular features (for example the crystal packing) can be well-defined. XRPD is in fact the best alternative to single crystal X-ray diffraction, when only a microcrystalline sample is available.

Expectedly, the molecular geometries of the studied MCs are very similar in the solid state. The annulated rings in the octahydroanthracene skele- tons show a half-chair conformation with three $\mathrm{CH}_{2}$ groups peaking above the plane, linking the electron-donor and electron-acceptor groups with the conjugated chain. The piperidine rings exhibit chair conformation with the nitrogen atom linked directly to the octahydroanthracene unit. As expected, the bond lengths and angles have very similar values in both compounds (the precision of derived parameters of MC-M is somewhat lower due to the use of XRPD to refine an all-organic structure).

Contrary to the similarities in the molecular conformations and bond lengths of both MCs, their crystal packing diagrams significantly differ (shown in Figs. 3 and 4). Even though they crystallize in crystallographically identical space groups $\left(P 2_{1} / n\right.$ and $\left.P 2_{1} / c\right)$, the relative orientation of the molecules differs. In MC-M (Fig. 3) the molecules are stacked head-to-tail forming columns, whether in MC-K (Fig. 4) they orient themselves in a headto-head fashion.

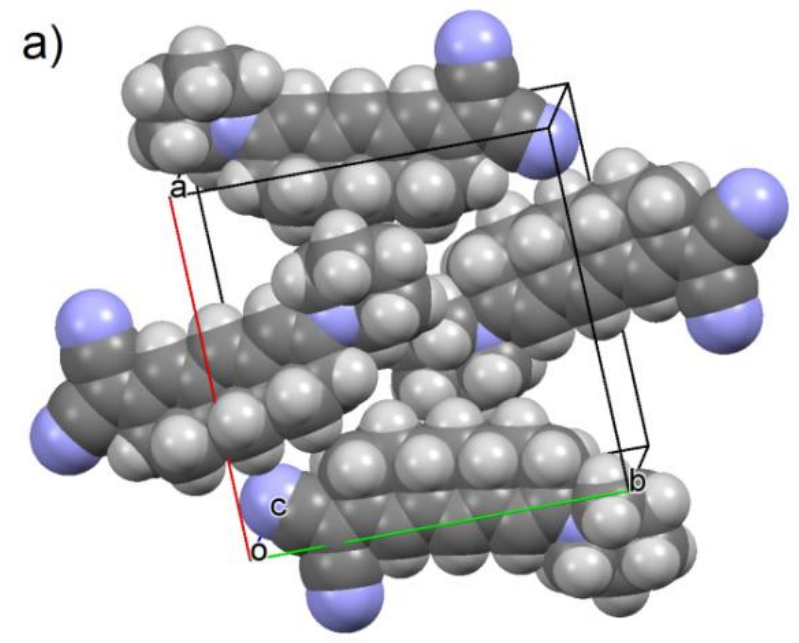

b)

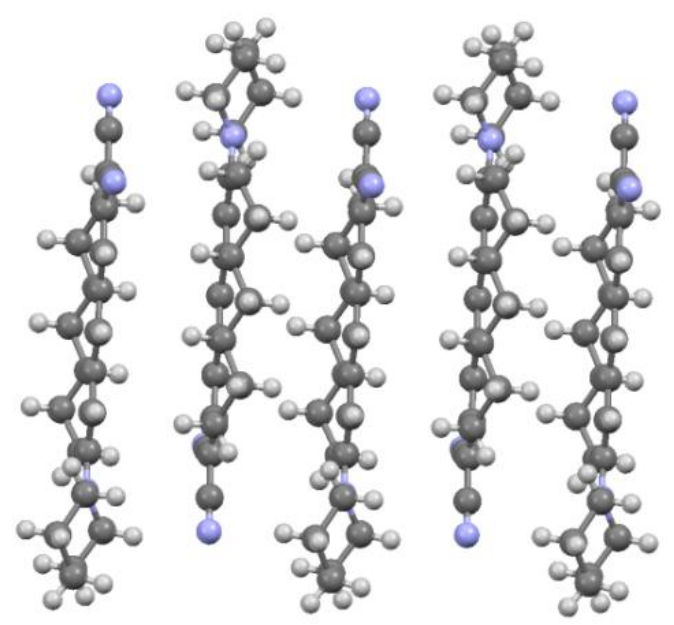

Fig. 3. a) Crystal packing diagram and b) head-to-tail stacking of the molecules of MC-M 
a)
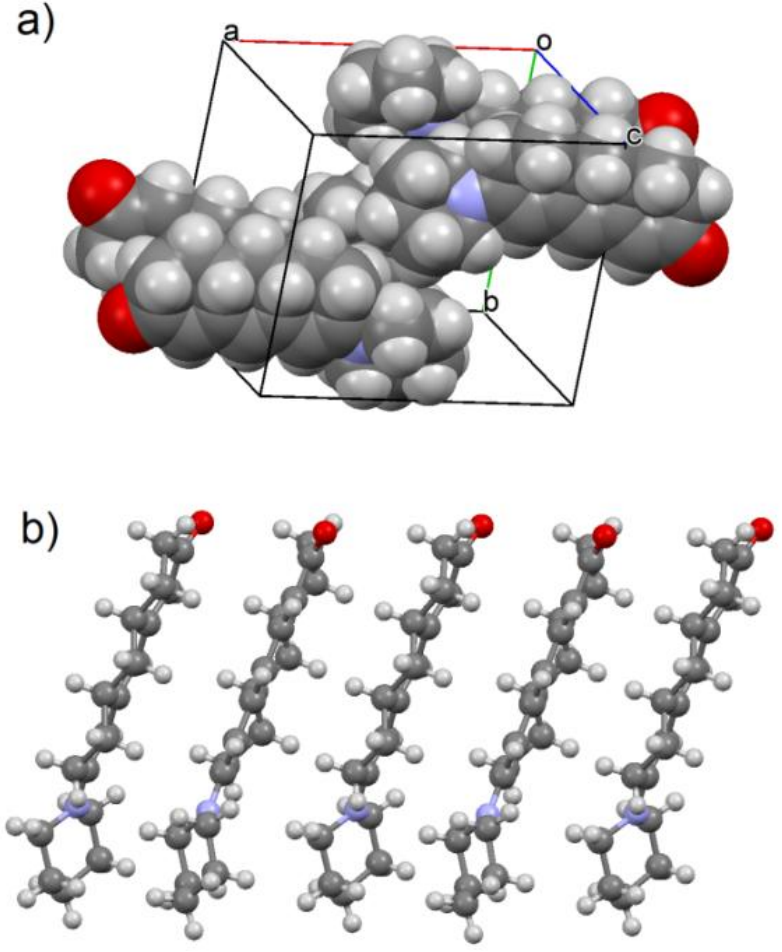

Fig. 4. a) Crystal packing diagram and b) head-to-head stacking of the molecules of MC-K

a)

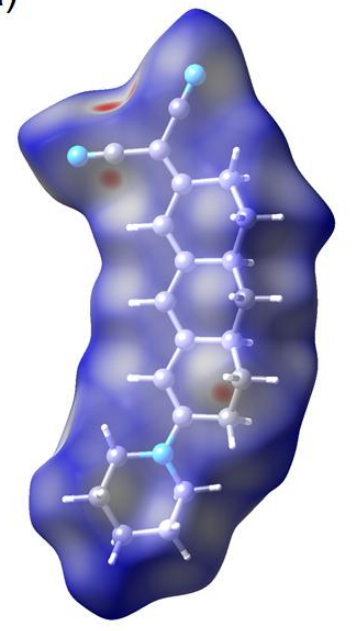

b)

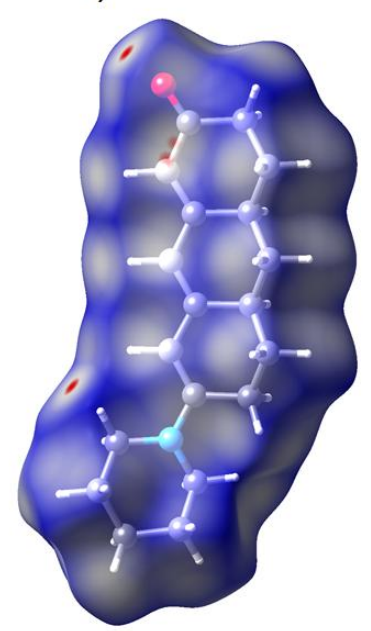

c)

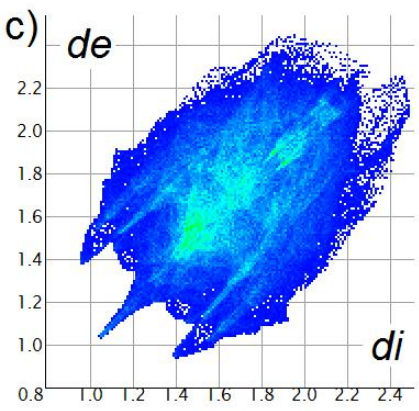

d)

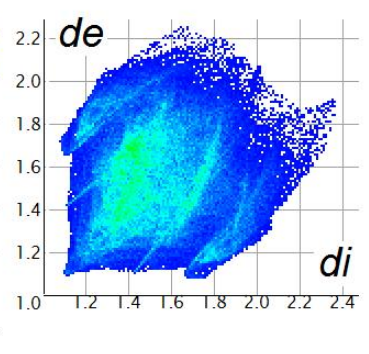

Fig. 5. Hirshfeld surfaces based on the crystal structures of a) MC-M and b) MC-K, together with the corresponding fingerprint plots given in c) and d) respectively
These differences might originate from the increased bulkiness and rotational flexibility of the malononitrile group as compared to the small ketone group directly linked to the octahydroanthracene skeleton. In both MCs, the electron-acceptor groups are weakly bonded via nonclassical hydrogen bonds to the piperidine $\mathrm{CH}_{2}$ groups of the neighbouring molecules. In the crystal structure of MC-M close contacts of the malononitrile group with the heptamethine $\mathrm{CH}_{2}$ groups are also evident.

Plotting and analyzing the Hirshfeld surfaces of a given crystal structure provides a very convenient way for studying and visualizing intermolecular contacts in the crystal packing [10]. The generated Hirshfeld surfaces of MC-M and MC-K are presented in Figure 5, together with the respective characteristic fingerprint plots of atomic contacts. The regions with red colour indicate shorter contacts within neighbouring molecules. The bulkiness of the malononitrile group (as compared to the small ketone group) is reflected in a more complicated and wider-spread fingerprint plot.

\subsection{Vibrational properties of $\mathbf{M C}-\mathbf{M}$ and $\mathbf{M C}-\boldsymbol{K}$}

Figure 6 presents the IR spectra of MC-M and MC-K recorded in the solid state. The highwavenumber region (spreading from $4000 \mathrm{~cm}^{-1}$ to $1700 \mathrm{~cm}^{-1}$ ) is dominated by the IR active stretching vibrations of the aliphatic $\mathrm{C}-\mathrm{H}$ bonds. In the molecular structure of both dyes there are two types of $\mathrm{C}-\mathrm{H}$ bonds, depending on the hybridization of the carbon atom: $\mathrm{C}=\mathrm{CH}-\mathrm{C}$ and $\mathrm{C}-\mathrm{CH}_{2}-\mathrm{C}$. Accordingly, two bands are noticed in the IR spectrum of MC-M (centred at wavenumbers of 2923 $\mathrm{cm}^{-1}$ and $\left.2851 \mathrm{~cm}^{-1}\right)$ and three in the spectrum of MC-K $\left(2937 \mathrm{~cm}^{-1}, 2855 \mathrm{~cm}^{-1}\right.$ and $2831 \mathrm{~cm}^{-1}$; splitting of the second band probably originates from nonclassical hydrogen bonding or from the presence of impurities in the bulk of MC-K).

The $\mathrm{C} \equiv \mathrm{N}$ stretching vibration is $\mathrm{IR}$ active and observed as a very strong band, centred at $2190 \mathrm{~cm}^{-1}$, in the spectrum of the malononitrile compound, and is expectedly absent in the spectrum of the ketone analogue.

In the spectrum of MC-K a strong band centred at $1621 \mathrm{~cm}^{-1}$ is observed and can be assigned to the ketone $\mathrm{C}=\mathrm{O}$ stretching vibration, this band is absent in the spectrum of MC-M. The observed bands in the low-wavenumber region of the IR spectrum can be used to discriminate among MCs with different functional groups. These peaks (positioned at wavenumbers below $1700 \mathrm{~cm}^{-1}$ ) are accredited to a number of IR active modes: (pre- 
dominantly) $\mathrm{CH}$ and $\mathrm{CH}_{2}$ bending and rocking vibrations, $\mathrm{C}-\mathrm{C}$ skeleton vibrations and coupled modes.

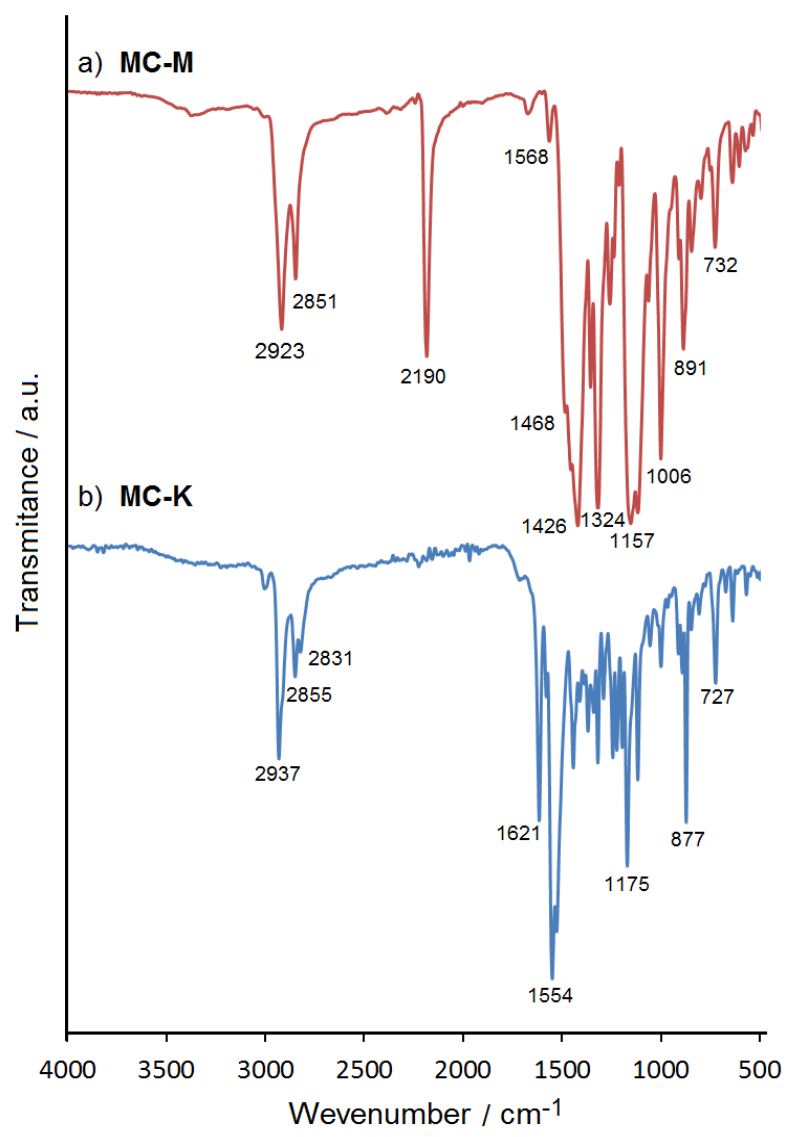

Fig. 6. IR spectra of a) MC-K and b) MC-M in the solid state. The wavenumber values of selected strong bands are displayed.

\subsection{Optical properties of $\mathbf{M C}-\mathbf{M}$ and $\mathbf{M C}-\boldsymbol{K}$}

MC organic dyes are designed to follow the electron push-pull molecular concept. Namely, they are chemically assembled by attaching electron-donor and electron-acceptor groups at opposite termini of a conjugated (in the present case heptamethine) moiety. Their overall electronic structure can be described by a superposition of a neutral and a zwitterionic resonance form. The push-pull molecular systems can be readily visualized by plotting the ESP surfaces of the MCs molecules. As presented in Figure 7, negative ESP (depicted in red colour) is observed around the electron-withdrawing groups and in the region of the lone electron pair of the nitrogen atom. The relative size of the negative ESP around the nitrogen atom, compared to the negative ESP around the electron-acceptor group, can be used to indicate the electron-withdrawing strength of the attached functional group. The relative size of the negative ESP on the MC-K nitrogen atom is bigger, compared to the ESP region around the nitrogen atom in MC-M. This indicates that the ketone group is a much weaker electron-accepting group compared to the malononitrile. It is expected that the presence of different electron-acceptor functional groups, with significantly different electron-accepting capability, will give rise to pronounced differences in the corresponding UV-vis absorption spectra.
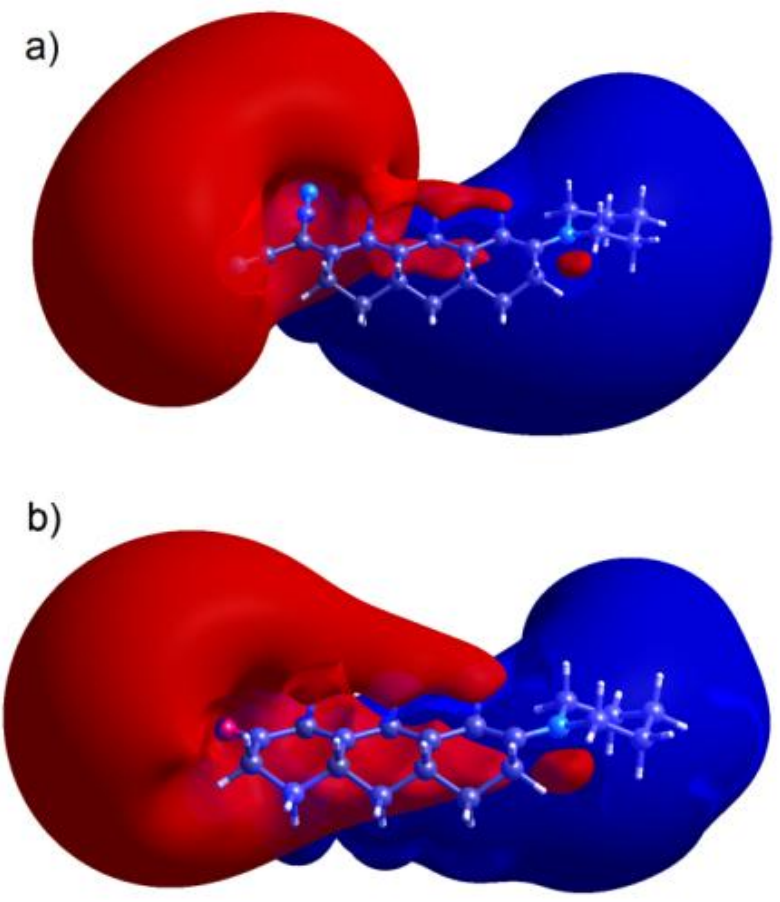

Fig. 7. ESP calculated for the molecules of a) MC-M and b) MC-K (with geometries as observed in the respective crystal structures) showing the push-pull molecular design

Figure 8a presents the absorption UV-vis spectra of MC-M recorded in the solid state and in different solvents. The absorption spectra are dominated by a strong bands originating from $0-0$ vibronic transitions, which are characteristic for MCs with strong electron-acceptor moieties (presumably due to the similar structure and polarizability of the electronic ground and first excited state) [18]. In the solid state, MC-M absorbs UVvis radiation with wavelengths shorter than $700 \mathrm{~nm}$ giving rise to intensive purple colour.

In the UV-vis spectra of MC-K, presented in Figure $8 b$, the $0-1$ vibronic transitions are the major contributors of absorption. This is expected for MCs assembled by incorporating a weak electron-acceptor group, because the electronic ground state is less polarized than the first excited electronic state [18]. MC-K absorbs UV-vis radiation 
with wavelengths shorter than $550 \mathrm{~nm}$ giving rise to intensive orange colour.
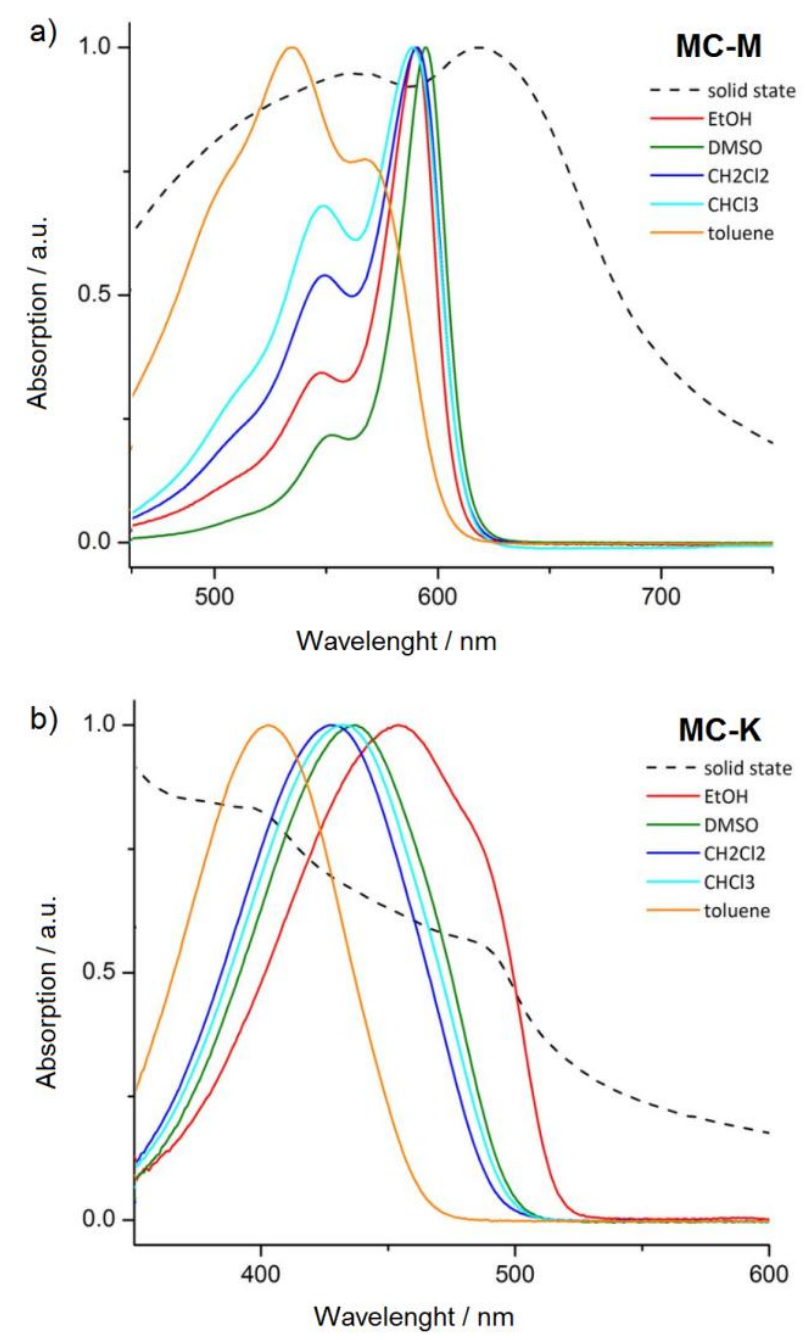

Fig. 8. UV-vis absorption spectra of a) MC-M and b) MC-K recorded in the solid state (dotted line) and in different solutions (solid coloured lines)

The solvatochromism of the studied MCs (Fig. 8) was previously discussed [9]. In the present contribution the accent is put on the solid-state absorption features. The UV-vis spectra recorded from crystalline MCs show significantly broader bands, which is characteristic for solid state materials. For both pigments a bathochromic shift is evidenced in the solid-state spectra, as compared to the spectra in different solutions. The largest shift is observed with respect to the spectra recorded in toluene solution (with toluene being a non-polar solvent). Generally, the spectral shift decreases with the increase of the polarity of the solvent molecules. Interestingly, the absorption spectrum of MC-K in the solid-state shows very small maxima deviations compared to the spectrum recorded in an ethanol solution (with ethanol being a polar solvent). These bathochromic shifts of absorption maxima can be ascribed to at least two effects that could arise upon solidifying the molecules: a) changes to the energies of the singlet $S_{0}$ and/or $S_{1}$ states and b) changes to the contributions of different vibronic transitions upon UV excitation. To elucidate the real nature of the solid-state absorption features sophisticated theoretical modelling and calculations are needed.

The UV-vis absorption window of solidified MC-M is enlarged for ca. $70 \mathrm{~nm}$ in the visible region, compared to the absorption in different solutions (Fig. 8a). In the case of MC-K, the absorption window exhibits much smaller enlargement (Fig. 8b). The different spectral shift and broadening can be explained considering several factors. Namely, the packing of the molecules (head-to-tail $v s$. head-to-head in MC-M and MC-K, respectively) can contribute to changes in absorption. The energies of the $0-0$ and $0-1$ vibronic transitions (occurring in MC-M and MC-K, respectively) can be influenced by solidification. In addition, the strength of electron-withdrawing groups might be affected when the molecules are densely packed in close proximity. To decipher this phenomenon, systematic structural, spectroscopic and theoretical studies on different dyes are necessary.

Materials with tuneable UV-vis absorption in a broad spectral region are important in the production of new, dye-sensitized solar cells and pigments in general.

\section{CONCLUSIONS}

Two MC dyes containing different electronacceptor functional groups (malononitrile, MC-M and ketone, MC-K) were synthetized and crystallized to study their physical properties. IR spectroscopy proved the presence of the corresponding functional groups in the solidified samples. The crystal structure of MC-M was solved $a b$ initio from XRPD data. Both compounds show very similar molecular geometries in the solid state, with a half-chair conformation of the three $\mathrm{CH}_{2}$ groups in the heptamethine moiety, peaking above the plane of the octahydroanthracene skeleton. The piperidine rings exhibit chair conformation. Although the molecules crystallize in the same crystallographic space group and have similar molecular geometries, they exhibit different crystal packing diagrams. In MC-M they are head-to-tail packed, whether in MC-K head-to-head packed. Therefore, it can be concluded that the introduction of bulky and highly flexible functional group (as it is the malononitrile compared to the ketone) has a 
significant effect on the crystal packing fashion of MCs. The crystal structures were analyzed in detail with inspecting the Hirshfeld surfaces, revealing different short contacts within neighbouring molecules in the two MC crystals. The absorption characteristics of MC-M and $\mathbf{M C}-\mathbf{K}$ were rationalized with the push-pull chemical design, which was visualized by plotting the ESP calculated using the molecular geometries as determined by the crystallographic analysis. The solid-state absorption spectra of these MCs pigments with different electron-acceptor groups and dissimilar crystal packing were experimentally studied. It was noticed that different bathochromic spectral shift occurs (when the solid-state spectra were compared to the spectra recorded in solution). It can be concluded that the spectral shifts are increasing inversely to the solvent molecules' polarities: The largest shifts were noticed with respect to the spectra recorded in toluene solution, whether the smallest shifts to those in ethanol solution. Changes to the energies of the singlet $S_{0}$ and/or $S_{1}$ states and/or changes to the contributions of different vibronic transitions upon UV excitation were pointed-out as possible reasons for the experimental observations. In addition, it was evidenced that the solidification of the MCs pigments influences the absorption-peak shape, leading to larger broadening of absorption in the visible region of $\mathbf{M C}-\mathbf{M}$, as compared to $\mathbf{M C}-\mathbf{K}$.

Acknowledgements. The authors are thankful to Ms. Nina Stitz for her help during the collection of the solid-state UV-vis spectra. K.C.K. acknowledges the Carl Zeiss Stiftung for a $\mathrm{PhD}$ fellowship.

\section{REFERENCES}

[1] A. Kazlauciunas, The role of colorants in the generation, storage, and output of digital still images, Color. Technol., 130, 8-12 (2014).

[2] R. L. Gieseking, S. Mukhopadhyay, C. Risko, S. R. Marder, and J.-L. Brédas, 25th Anniversary Article: Design of Polymethine Dyes for All-Optical Switching Applications: Guidance from Theoretical and Computational Studies, Adv. Mater., 26, 68-84 (2014).

[3] M. Wainwright, Dyes in the development of drugs and pharmaceuticals, Dyes Pigments, 76, 582-589 (2008).
[4] S. H. Kim, Functional Dyes, Elsevier, 2006.

[5] F. Würthner, T. E Kaiser, C. R. Saha-Möller, Aggregates: From Serendipitous Discovery to Supramolecular Engineering of Functional Dye Materials, Angew. Chem. Int. Ed., 50, 3376-3410 (2011).

[6] A. S. Abd-El-Aziz, E. A. Strohm, R. M. Okasha, Design and spectroscopic characterization of novel series of near infrared indocyanine dyes, J. Mol. Struct., 1091, 228235 (2015).

[7] A. V. Kulinich, A. A. Ishchenko, Merocyanine dyes: synthesis, structure, properties and applications, Russ. Chem. Rev., 78, 141-164 (2009).

[8] U. Lawrentz, W. Grahn, K. Lukaszuk, C. Klein, R. Wortmann, A. Feldner, and D. Scherer, Donor-Acceptor Oligoenes with a Locked all-trans Conformation: Synthesis and Linear and Nonlinear Optical Properties, Chem.-Eur. J., 8, 1573-1590 (2002).

[9] K. C. Kre $\beta$, T. Fischer, J. Stumpe, W. Frey, M. Raith, O. Beiraghi, S. H. Eichhorn, S. Tussetschläger, S. Laschat, Influence of Chromophore Length and Acceptor Groups on the Optical Properties of Rigidified Merocyanine Dyes, Chem. Plus Chem., 79, 223-232 (2014).

[10] M. A. Spackman, D. Jayatilaka, Hirshfeld surface analysis, Cryst. Eng. Commun., 11, 19-32 (2009).

[11] M. A. Spackman, J. J. McKinnon, D. Jayatilaka, Electrostatic potentials mapped on Hirshfeld surfaces provide direct insight into intermolecular interactions in crystals, Cryst. Eng. Commun., 10, 377-388 (2007)

[12] Bruker AXS, Topas, version 4.2. 2007.

[13] A. A. Coelho, Indexing of powder diffraction patterns by iterative use of singular value decomposition, J. Appl. Cryst., 36, 86-95 (2003).

[14] G. S. Pawley, Unit-cell refinement from powder diffraction scans, J. Appl. Cryst., 14, 357-361 (1981).

[15] A. A. Coelho, Whole-profile structure solution from powder diffraction data using simulated annealing, $J$. Appl. Cryst., 33, 899-908 (2000).

[16] H. M. Rietveld, A profile refinement method for nuclear and magnetic structures, J. Appl. Cryst., 2, 65-71 (1969).

[17] CrystalExplorer (Version 3.1), S. K. Wolff, D.J. Grimwood, J. J. McKinnon, M. J. Turner, D. Jayatilaka, M. A. Spackman, University of Western Australia, 2012.

[18] H. Mustroph, K. Reiner, B. Senns, J. Mistol, S. Ernst, D. Keil, L. Hennig, The Effects of Substituents and Solvents on the Ground-State $\pi$-Electronic Structure and Electronic Absorption Spectra of a Series of Model Merocyanine Dyes and Their Theoretical Interpretation, Chem.-Eur. J., 18, 8140-8149 (2012). 